\title{
The Impact of Competitive Strategy and Intellectual Capital on SMEs Performance
}

\author{
Istianingsih and Robertus Suraji \\ Universitas Bhayangkara Jakarta Raya \\ Email: \\ istisastro@yahoo.com
}

\begin{abstract}
This study aims to examine the impact of competitive strategies and intellectual capital on the performance of Small and Medium Enterprises (SMEs). The research sample is the owners of SMEs in the Banten region. The number of final samples obtained that can be included in the test is as many as 181 respondents of SME owners or $60.33 \%$ of the total intended respondents. The data analysis technique used is regression with structural equation models. The results showed that the Competitive Strategy proved to have a positive effect on the success of SMEs. The choice of the right competitive strategy can improve SME performance. Intellectual Capital Management is also proven to have a positive effect on the success of SMEs. The greater the Intellectual Capital, the more it will encourage SMEs to perform better. The implication of the results of this study is that in order to improve the competitiveness and success of SMEs, it is necessary to choose the right competitive strategy and manage their intellectual capital well.
\end{abstract}

Keyword: competitive strategy, intellectual capital, SMEs, Banten.

\begin{abstract}
Abstrak: Tujuan penelitian ini adalah menguji pengaruh strategi bersaing dan kepemilikan modal intelektual terhadap keberlangsungan Usaha Kecil dan Menengah (UKM). Sampel akhir penelitian adalah 181 responden pemilik UMKM di Banten. Teknik analisis data yang digunakan adalah regresi dengan structural equation model. Hasil penelitian menunjukkan bahwa Strategi Bersaing terbukti secara signifikan berpengaruh positif terhadap keberhasilan UMKM. Pilihan strategi bersaing yang tepat dapat meningkatkan performa UMKM. Pengelolaan Modal intelektual juga terbukti secara signifikan berpengaruh positif terhadap keberhasilan UMKM. Semakin besar Modal Intelektual maka akan semakin mendorong UMKM berkinerja lebih baik sehingga kemampuannya bersaing akan semakin kuat. Hasil penelitian berimplikasi bahwa guna meningkatkan daya saing dan keberhasilan UMKM perlu pemilihan strategi bersaing yang tepat dan mengelola modal intelektualnya dengan baik.
\end{abstract}

Kata kunci: strategi bersaing, modal intelektual, UMKM, Banten. 


\section{INTRODUCTION}

As the foundation of the Indonesian economy, the development of the managerial system of the Small and Medium Enterprises (SMEs) sector has not been given much attention by stakeholders. The main obstacle faced by the managers of SMEs in addition to capital is the application of professional management. The success of Small and Medium Enterprises (SMEs) is highly dependent on the ability of these business owners to manage their business.

The development of the Indonesian economy is supported by the many people's businesses that also develop with a variety. These community businesses range from highvalue businesses to small and medium-sized businesses. Small and medium-sized businesses are also referred to as Micro, Small and Medium Enterprises (MSMEs). This business group is very dominant, around $90 \%$ of the total companies in Indonesia. In reality, MSMEs have proven to be capable of supporting the Indonesian economy during the monetary crisis.

(Yuli, 2017) shows the large role of MSMEs in supporting the development of the Indonesian economy. The proportion of MSMEs dominates business operators up to 99.99\%. The amount consists of 56.54 million business units. This finding proves that MSMEs still exist even when the monetary crisis hit Indonesia in 1998 and 2008.

MSMEs have higher endurance than large companies. The strength of MSME lies in its ability to stand without relying on large capital. MSMEs also do not rely on foreign debt. Even when there is a fluctuation in currency exchange rates, MSMEs are still able to survive even though they are not free from various obstacles.

The problem often faced is the management of intellectual capital and the determination of competitive strategies that will be used by SME owners or management. This SME management capability is a representation of the management of the company's unique resources. This unique resource is an important intellectual capital for SMEs to consider.

(Andi, 2016) state that the determinants for the development of MSMEs are increasing human resources, technology utilization, capital access, marketing access, and access to information and management. The amount of financial capital owned by MSME entrepreneurs will greatly depend on the ability of MSME entrepreneurs to manage their intellectual capital in order to achieve an increase in the success of SMEs. Intellectual capital is crucial for the success of MSME entrepreneurs to be able to manage their financial capital.

This intellectual capital includes three components, namely structural capital or structural capital, human capital, and relational capital with other parties owned by SMEs. These three components of intellectual capital are based on the research of (Istianingsih, 2012). She tested and proved the positive impact of managing intellectual capital on the performance of public companies. However, research conducted with the aim of examining the impact of intellectual capital management on the effectiveness of MSME management in particular has not been found. Each component of intellectual capital should be managed properly in order to be beneficial for improving the performance of MSMEs.

In addition to the ability to manage intellectual capital, the selection of competitive strategies used by SMEs will also largely determine the level of SME success. The results of the study of (Qristin, 2018) stated that the strategy to develop (MSME) really requires credit support from banks. Competition among similar SMEs which are very numerous is 
an important factor that needs attention. The best strategy is to find an alternative solution so that SMEs can win business competition. A competitive strategy outlines how business units or companies compete in the same industry. This strategy allows the company to gain a competitive advantage over its competitors. Several studies have found that a company that has competence in various functional fields, will be better able to remain competitive in the market (Istianingsih, 2012; Adi, 2016; and Qristin, 2018).

This study aims to examine the factors that determine the success of the development of MSMEs. The factors tested were the selection of competitive strategies and management of intellectual capital. This research was conducted in the area of Banten Province. The selection of Banten as an area to be studied in the development of SMEs is related to the selection of competitive strategies and management of intellectual capital based on the consideration that the Province is demographically very strategic because it is a connecting route for the islands of Java and Sumatra. The strategic position of the region allows SMEs in Banten to develop rapidly. This is consistent with data from the Banten MSME Center which states that currently each region in the Banten region already has a variety of superior products (Rudiantoro and Sylvia, 2012).

However, MSMEs have not marketed the product in the right place. Furniture, handicraft, and processed UMKM Banten products are still traditionally sold. The number of MSMEs recorded in the Banten Chamber of Commerce and Industry (Kadin) is around 7,700 business units. Even though the total number actually reached 900 thousand MSMEs. It is hoped that the results of this study will become the foundation for the management of the MSMEs in the Banten region in order to improve the effectiveness of MSME management in Banten. This research is in line with the Main Work Program of the Cooperative and UMKM offices of Banten. The program is to enhance the ability of competitiveness, and enhance the ability of MSME Institutional and human resources (Banten Cooperative and UKM Office, 2020). If UMKM has grown sufficiently, it will eventually strengthen the economy of the Banten region and more broadly support national economic growth.

\section{THEORITICAL REVIEW}

Resource Base View Theory (RBV). RBV is based on the perception that companies compete because of the heterogeneous distribution of resources among companies (Barney, 1991). The diversity of these resources is the cause of differences in financial performance between companies (Peteraf, 1993). Contrary to the focus of an external perspective that seeks to link corporate strategies with competitive positions and environmental factors, the resource-based perspective focuses on the benefits derived from the organization's internal resources. Adherents of this theory believe that the company's internal resources are the main force. Companies can achieve profits and improve performance by gathering resources that produce economic value. This economically valuable resource is relatively rare. Company profits must also be achieved through increasing competitive efforts by imitating, acquiring, or substituting (Barney, 1991).

The implication of this theory is that the company's unique resources will be able to be used to win the competition. The uniqueness of this resource should not be easily imitated. In this research context, intellectual capital is the company's unique resource. Intellectual capital is usually also unique and rare. In addition to intellectual capital, 
competitive strategies are also the company's unique resource. Both of these unique resources should be well managed to increase the success of MSMEs.

Decision Usefulness Theory. Financial statements are the final process of bookkeeping and accounting. This report plays a strategic role in economic decision making. Theoretically, the decision usefulness approach states that the function of financial statements as useful information for those who are interested in the information will have an impact on their decision making (Deegan, 2002).

For investors, financial statement information is useful for determining their investment decisions. Various information related to company performance can be found in the financial statements. Investors can assess the company's future prospects by reading their financial statements.

For banks, financial statements are a formal requirement for companies to apply for credit. In banking, the decision to provide credit is based on several criteria for the financial statements. There fore it is natural that most MSMEs in Indonesia are difficult to get access to bank credit. This is because most MSMEs have not been able to make financial reports that meet banking standards. Besides that Banten SMEs are still unable to determine the competitive strategy that best suits their abilities.

Hypothesis Development. MSMEs need to adjust the right competitive strategy to achieve competitive advantage. The strategy must be in accordance with the type of resources used. The match between strategy and resources is absolutely necessary to win the competition. (Bukh et al., 2005) argue that intellectual capital has more influence on organizational structure and strategy than capital from capital market activities. Fit between strategy and intellectual capital is expected to improve organizational performance.

Intellectual capital is beneficial for improving organizational performance. Referring to Resource-based View theory, the company's unique resources provide a great support for its ability to compete. In line with the RBV theory, ownership of intellectual capital can increase the success of MSMEs. Intellectual capital is the company's unique resource. Intellectual capital is difficult for other companies to emulate. Research examining the effect of intellectual capital on company competitiveness is carried out by (Istianingsih, 2012). The results of his research indicate that the higher the intellectual capital, the more effective the management of SMEs will be. When a company has adequate intellectual capital and manages it well, its ability to compete will increase. Therefore, this study proposes the first hypothesis as follows:

H1: Intellectual Capital Has a positive effect on the effectiveness of MSME management.

To improve the effectiveness of MSME management, management must have a strategy that is appropriate to the business environment. In other words companies must be able to take advantage of their environment in order to excel by choosing the most appropriate strategy. Some MSMEs have not been able to survive when the strategies they have taken are no longer compatible with their operating environment. State that competitive strategies are important mediators. Competitive strategies affect the company's strategic response to the new environment. The company's ability to adapt to the environment must be demonstrated by choosing the right strategy. 
(Miles and Snow 1978) give direction that there are 4 types of competitive strategies: prospector, defender, analyzer, and reactor. The four strategies can be chosen which one is most suitable to the characteristics of MSME businesses. Prospectors are strategies that are concerned with innovation, and creativity in creating new products or new markets. Companies with this strategy strive to always be ahead of the competition. They do internal efficiency in innovating, and being creative. Prospectors need skilled staff. Therefore they will tend to look for human resources who are creative and able to create change even if it is expensive.

Defenders emphasize stability, and business survival. They stay in the core business without much change. They attach great importance to long-term stability. Meanwhile Analyzers voters will use a strategy between defenders and prospectors. They don't dare to take big risks. They tend to prioritize their services to the market. From the perspective of the Reactors strategy selector, it will depend more on the environment. They are less focused on changing the competitive environment. What they do is reduce costs including the cost of human resources. They are more concerned with saving in all aspects.

Reactors are a type of competitive strategy suitable for companies that are more pressured by the environment. Voters of this strategy tend to pay less attention to changes in the environment and the competitive system.

The competitive strategy model chosen will provide a framework for management. MSME managers will use this strategy to identify the characteristics of the business and its suitability with the type of strategy taken. This model is often used in empirical research to determine the overall strategy (Sumbogo and Dara, 2020); (Eko and Rachma, 2018). Which strategy is most effective in order to win compete cannot be as certained. Need to understand and recognize the strategy and define it well in order to succeed. (Miles and Snow, 1976) provide various alternative strategies so that companies can choose the right strategy for the business situation.

In terms of managing MSMEs, the typology of competitive strategy enables companies to take strategic steps. Competitive strategies play a role in improving the management of MSMEs towards a more effective direction. In order to increase the effectiveness of MSME management, it is necessary to choose a strategy that is more towards the prospector to achieve competitive advantage. In this case the company must be able to conduct an analysis of its environment. The company's ability to identify the needs of its strategy will further enhance the durability of its competition. The higher the resilience in competition will further strengthen the opportunity for MSMEs to succeed in the market.

H2: Competitive strategy has a positive effect on the effectiveness of MSME management.

\section{METHODS}

Object of research. The object of this research is the level of effectiveness of SME management that is associated with the suitability of competitive strategy selection, and the ability to manage intellectual capital. Therefore, the variable that is the object of this research is the level of success of SMEs as the dependent variable. Meanwhile, the accuracy of the selection of competitive strategies, and management of intellectual capital are research objects which are the independent variables observed in this study. 
Population and Sample Selection Techniques. The population of this research is all MSMEs in the area of Banten Province. While the research sample is MSMEs in the Banten province which were selected through convinience sampling methods. The convinience method was chosen with the consideration that there is an easy access to MSME managers so that it is possible to get an adequate number of samples. The minimum number of samples needed is 5 times the number of indicators. The determination of the number of samples follows the rule of thumb structural equation model that is 5 times the research indicator (Hair et al, 2008). The number of indicators in this study was 37 . The minimum number of samples needed was 185 respondents.

\section{Variable Definition and Operations}

Dependent Variable. The dependent variable in this study is the effectiveness of MSME management. What is meant by the effectiveness of MSME management in this study is the level of success of MSME management. This variable will be measured by the dimensions of success in terms of financial and non financial. The measure of financial success is profitability as measured by the ratio of return on assets (ROA). While the measure of the effectiveness of non-financial management is used a questionnaire that states about the position of SMEs compared to its competitors which is an indicator of the success of SMEs.

Variabel Independen. This research has two independent variables. The first independent variable is the selection of a competitive strategy. The competitive strategies used in this study include the prospector, defender, analyzer and reactor strategies. The four strategies are the concept of competitive strategy proposed by (Miles and Snow, 1978). To measure the variables of the competitive strategy used a questionnaire. Respondents who are SME owners are asked to fill out a questionnaire used in (Sumbogo and Dara, 2020); (Eko and Rachma, 2018).

The last independent variable in this study is the management of intellectual capital. In this study intellectual capital is defined as intangible resources in the form of knowledge, experience, ability to manage relationships, the organization of technology and information, skills, and professionalism that can be managed and utilized by management to create value in order to achieve sustainable competitive advantage for the company (Istianinigsih, 2012). Intellectual capital in this study is divided into three dimensions namely structural capital, human capital, and relationship capital. The three dimensions of intellectual capital will be measured by 30 indicators in the research questionnaire. To measure human capital 10 indicators are used, relationship capital is 11 indicators and structural capital is 9 indicators.

Data Collection Technique. The data used to test the hypotheses in this study are primary data. The data was obtained directly from the source, namely the owners of MSMEs in Banten. This data was obtained through a questionnaire distributed to respondents, namely UKM in Banten Province. The questionnaire distributed was a list of questions prepared by researchers in which each question relates to the problem of choosing competitive strategies, and management of intellectual capital at MSMEs in the area of Banten Province.

Data Analysis Technique. Before testing hypotheses, an analysis of the validity and reliability of the data is first performed. Validity analysis is performed on the basis of corrected item-Total Correlation. Meanwhile, to test the reliability of the data used Cronbach Alpha size. To test the hypothesis used multiple linear regression. The method 
used is structural equation modeling (SEM) because it suits the research objectives. This method is more appropriate than other SEM techniques because the dependent variable and the independent variable are both built with formative indicators. By using SEM, latent variables can be analyzed with formative indicators (Ghozali, 2011). The proposed model, which is a model that regresses the effectiveness of MSMEs management variables with intellectual capital management variables, and the selection of competitive strategies. The mathematical formula used to test the hypothesis is as follows:

MSMEs Perform $=\alpha_{0}+\alpha_{1} \mathrm{IC}+\alpha_{2}$ Strategy $+\varepsilon$

Where:

$\begin{array}{ll}\text { MSMEs Perform } & : \text { Success rate of managing MSMEs } \\ \text { IC } & : \text { Intellectual Capital Management } \\ \text { Strategy } & : \text { The accuracy of the selection of competitive strategies } \\ \varepsilon & : \text { error term }\end{array}$

Testing is done by following the applicable stages in SEM. To test the hypothesis use Lisrel 8.72 software. The method used is robust maximum likelihood. There are two steps of testing that must be performed (Hair et al., 2008). The two steps are: (1) Testing the suitability of the measurement model. (2) Structural model compatibility testing.

This analysis is carried out on the coefficients of structural equations by specifying a certain level of significance. Analysis of this structural model is to test the hypotheses proposed in this study. For the significance level used is 0.05 . Thus, the criteria for the $t$ value of the structural equation of the regression results must be greater or equal to 1.96 or to be practically greater than 2 (Wijanto, 2008).

\section{RESULTS AND DISCUSSION}

Descriptive Research Object. This study uses primary data obtained through a questionnaire. Of the 300 questionnaires sent to respondents, the number returned was 187 questionnaires. So the response rate from the distribution of this questionnaire is $59 \%$ of the total questionnaire sent. Of the returned numbers, there were 6 questionnaires that could not be included as samples because they did not meet the sample selection criteria or were incomplete. The final number of samples obtained that can be included in the test is 181 respondents or $60.33 \%$ of the total intended respondents. Thus the number of respondents in this study, it can be stated that the number of samples has represented the population.

The data collection period of this study was four months from April 1, 2014 to August 31,2014 . In distributing this questionnaire, researchers went directly to the company (SME) where the respondent worked, through several contact persons in the company, and also through electronic mail.

\section{Test Results for Indicator Variable Validity}

Validity of Indicator Variables from Intellectual Capital Variables. Intellectual capital variables in this study were divided into 3 categories, namely human capital, relationship capital, and structural capital. From these 3 dimensions there are a total of 30 item indicators 
namely IC1 to IC30. From the results of running the Lisrel program for 10 indicators of intellectual capital the results show that indicators from IC1 to IC10 have a standardize loading factor value below a critical value of 0.5 . The ten indicators do not meet the loading factor criteria above 0.5 . Thus IC1 through IC10 cannot be used in further testing. While as many as 16 indicators from IC11 to IC26 values have a critical value of 1.96 and standardized loading factor values above 0.5 . This means that as many as 16 indicators are valid, so these indicators do not have to be discarded and can be used in further testing. Table 1 presents a summary of the results of the validity of intellectual capital indicators that are proven valid.

Table 1. Standardized Loading Factor and t-value of Intellectual capital

\begin{tabular}{c|c|c|c}
\hline Indicator Variables & $\begin{array}{c}\text { Standardized } \\
\text { Loading Factor }\end{array}$ & t-value & $\begin{array}{c}\text { Validity } \\
\text { Conclusion }\end{array}$ \\
\hline IC11 & 0.76 & 6.52 & Valid \\
\hline IC12 & 0.75 & 6.32 & Valid \\
\hline IC13 & 0.62 & 7.78 & Valid \\
\hline IC14 & 0.64 & 6.74 & Valid \\
\hline IC15 & 0.68 & 6.52 & Valid \\
\hline IC16 & 0.79 & 8.22 & Valid \\
\hline IC17 & 0.73 & 8.22 & Valid \\
\hline IC18 & 0.74 & 7.78 & Valid \\
\hline IC19 & 0.76 & 6.74 & Valid \\
\hline IC20 & 0.66 & 6.74 & Valid \\
\hline IC21 & 0.58 & 8.22 & Valid \\
\hline IC22 & 0.76 & 7.78 & Valid \\
\hline IC23 & 0.64 & 6.74 & Valid \\
\hline IC24 & 0.68 & 8.22 & Valid \\
\hline IC25 & 0.78 & 7.78 & Valid \\
\hline IC26 & 0.66 & 6.74 & Valid \\
\hline
\end{tabular}

Validity of Competitive Strategy Indicators. This variable has 4 observed variables, namely Competitive Strategy (CS). These indicators abbreviated as CS from CS1 to CS4. From the results of running the Lisrel program for the four indicators of competitive strategy selection the results show that all indicators from CS1 to CS4 have a t value above a critical value of 1.96 and a standardized loading factor value above 0.5. This means that all indicators are valid, so there are no indicators that need to be discarded. All indicators of the competitive strategy selection (CS) variable can be used in further testing.

Table 2 presents a summary of the results of the validity of Competitive Srtategy indicators.

Table 2. Standardized Loading Factor and t-value of Competitive Srtategy

\begin{tabular}{c|c|c|c}
\hline Indicator Variables & $\begin{array}{c}\text { Standardized } \\
\text { Loading Factor }\end{array}$ & t-value & $\begin{array}{c}\text { Validity } \\
\text { Conclusion }\end{array}$ \\
\hline CS1 & 0.68 & 7.90 & Valid \\
\hline CS2 & 0.81 & 7.33 & Valid \\
\hline CS3 & 0.88 & 5.93 & Valid \\
\hline CS4 & 0.90 & 6.45 & Valid \\
\hline
\end{tabular}


Validity Indicators of Success of MSMEs. The next data processing is to look at all observable variables which are indicators of management effectiveness variables or the competitive success of MSMEs. Processing results show indicators from FP1 to FP4 other than FP3 have a t value above a critical value of 1.96 and a standardized loading factor value above 0.5 . This means that FP1 FP2 and FP4 are valid indicators, while FP3 is an indicator that must be discarded. Thus the indicators of success of MSMEs that can be used in the final test are only 3 indicators. Table 3 presents a summary of the results of the validity of Firm performance indicators.

Table 3. Standardized Loading Factor and t-value of Firm performance

\begin{tabular}{c|c|c|c}
\hline Indicator Variables & $\begin{array}{c}\text { Standardized } \\
\text { Loading Factor }\end{array}$ & t-value & $\begin{array}{c}\text { Validity } \\
\text { Conclusion }\end{array}$ \\
\hline FP1 & 0.64 & 6.52 & Valid \\
\hline FP2 & 0.78 & 8.22 & Valid \\
\hline FP3 & 0.44 & 1.78 & Not Valid \\
\hline FP4 & 0.66 & 6.74 & Valid \\
\hline
\end{tabular}

Reliability Test Results. Table 4 presents a summary of the results of the calculation of Construction Reliability and Variance Extracted for each latent variable.

Table 4. Value of Construct-Reliability and Variance-Extracted latent variables

\begin{tabular}{c|c|c|c}
\hline Latent Variable & $\begin{array}{c}\text { Construct-Reliability } \\
\text { Nilai }>=\mathbf{0 . 7 0}\end{array}$ & $\begin{array}{c}\text { Variance- } \\
\text { Extracted } \\
\text { Nilai }>\mathbf{= 0 . 5 0}\end{array}$ & Conclusion \\
\hline Intellectual Capital & 0.8212 & 0.5352 & Reliable \\
\hline Competitive Strategy & 0.8309 & 0.5238 & Reliable \\
\hline SMSe Performance & 0.8361 & 0.6302 & Reliable \\
\hline
\end{tabular}

Overall Model Match Analysis. Testing for structural models is preceded by testing the whole model. The goodness of the model can be seen based on the Goodness-of-fit Index (GFI) statistical indicators of the LISREL output (Hair et al., 2008). Overall a summary of the critical values of the overall model fit test can be seen from the summary in Table 5.

For the value of Chi Square obtained a number of 79.13 with a degree of freedom of 33. It is expected that a good value is for the value of chi square which is getting smaller, compared with the value of three times the value of the degree of freedom. LISREL estimation results for this criterion indicate that the suitability of the model seen from this criterion is quite good.

The value of Root Mean Square Error of Approximation (RMSEA) obtained a value of 0.080. This value indicates that the model is good or good fit because it meets the criteria for a good RMSEA value. The criterion for assessing a good RMSEA is that the RMSEA is smaller than 0.05 close fit. For RMSEA values between 0.05 to 0.08 , including the good fit category. If the value of this indicator is in the range between 0.08 to 0.10 it is said to be mediocore fit and finally for RMSEA greater than 0.10 is poor fit. So to judge a good model must have an RMSEA value less than 0.08.

Expected Cross-Validation Index (ECVI), used for comparison between models. The test results of this study showed the ECVI model value of 0.70 . While compared with the 
ECVI for Saturated Model is 0.65 and the ECVI for Independence model is 9.82. Because the ECVI model is closer to the ECVI saturated model compared to the ECVI for Independent model, it is concluded that the overall fit of the model is good (good fit).

The AIC model obtained a value of 141.78 Saturated AIC of 1322.00. As a comparison, the output for Independence AIC was 1994.04. Because the estimation results of the model turned out to be closer to saturated AIC, these results indicate that the model is good fit. The same is true for CAIC, which is closer to satirateed. So it was concluded that this model is good (good fit).

For the next values, Normed Fit Index (NFI), the number is 0.96. This value also shows that the model is good because the criteria for a good NFI value must be more than 0.90 . NNFI values obtained from the estimation of 0.96 . This value turns out to be greater than 0.90. Judging from this value, it indicates that the model is good (good fit).

Table 5. Overall Model Fit Test Results

\begin{tabular}{|c|c|c|c|}
\hline $\begin{array}{l}\text { Model Fit } \\
\text { Criteria }\end{array}$ & Fit Level Indicator & $\begin{array}{c}\text { Model Estimation } \\
\text { Results }\end{array}$ & Model Fit Level \\
\hline $\begin{array}{l}\text { Min Fit of Chi- } \\
\text { Square }\end{array}$ & Small value & 79.13 & Good fit \\
\hline NCP & Small value & 42.78 & Good fit \\
\hline $\begin{array}{c}\text { RMSEA } \\
\mathbf{P}(\text { close fit })\end{array}$ & $\begin{array}{l}\text { RMSEA }<0,08 \\
\mathrm{P}<0.05\end{array}$ & $\begin{array}{c}0,080 \\
0.0021\end{array}$ & Good fit \\
\hline ECVI & $\begin{array}{l}\text { Values smaller than Independence and } \\
\text { closer to the Saturated Model }\end{array}$ & $\begin{array}{l}\mathrm{M}^{*}=0.70 \\
\mathrm{~S}^{* *}=0.65 \\
\mathrm{I}^{* * *}=9.82\end{array}$ & Good fit \\
\hline AIC & $\begin{array}{l}\text { Values smaller than Independence and } \\
\text { closer to the Saturated Model }\end{array}$ & $\begin{aligned} \mathrm{M}^{*} & =141.78 \\
\mathrm{~S}^{* *} & =132.00 \\
\mathrm{I}^{* * *} & =1994.04\end{aligned}$ & Good fit \\
\hline CAIC & $\begin{array}{l}\text { Values smaller than Independence and } \\
\text { closer to the Saturated Model }\end{array}$ & $\begin{aligned} \mathrm{M}^{*} & =284.28 \\
\mathrm{~S} * * & =417.00 \\
\mathrm{I}^{* * *} & =2041.54\end{aligned}$ & Good fit \\
\hline NFI & $\mathrm{NFI}>0,90$ & 0.96 & Good fit \\
\hline NNFI & NNFI > 90 & 0,96 & Good fit \\
\hline CFI & CFI $>0,90$ & 0,98 & Good fit \\
\hline IFI & IFI $>0,90$ & 0,98 & Good fit \\
\hline RFI & RFI > 0,90 & 0,93 & Good fit \\
\hline $\mathbf{C N}$ & $\mathrm{CN}>200$ & 141.53 & Not Fit \\
\hline RMR & Standardized RMR $<0.05$ & 0.04 & Good fit \\
\hline GFI & $\begin{array}{l}\text { GFI }>0,90, \text { good fit; } 0.90<\text { GFI }>0.80, \\
\text { marginal fit }\end{array}$ & 0,94 & Good fit \\
\hline AGFI & $\begin{array}{l}\text { AGFI }>0,90, \quad \text { good } \\
0.90<\text { AGFI }>0.80, \text { marginal fit }\end{array}$ & 0.80 & Marginal fit \\
\hline
\end{tabular}

Another indicator to assess the goodness of fit model, the Comparative Fit Index (CFI), obtained a value of 0.98 from the Lisrel estimate. This number also means that the model is good (good fit) because the CFI value is already above 0.90 . For the IFI value obtained an estimated figure of 0.98 and an RFI of 0.93 . This value also shows that the model is good because its values are more than 0.90 . 
To assess whether the model is sufficiently representative of the sample, it can be seen from the critical $\mathrm{N}(\mathrm{CN})$ value. Lisrel estimation results show results of 141.53. These results indicate that the model still does not represent the data because its value is still less than 200. The RMR value below 0.05 is 0.04 indicating that the model is good or good fit.

To assess the Goodness of Fit Index (GFI) of this research model, it can be seen in the GFI value of the estimated model that is equal to 0.94 . The criteria to see this value are if the GFI is less than 0.80 poor fit, the GFI is between 0.80 and 0.90 marginal fit, and for GFIs whose values are above 0.90 are in the good fit category. The GFI value from this study was 0.94 , so from this indicator the model is good (good fit). Meanwhile, the AGFI value of 0.87 indicates that the match is also quite good because the estimated value is not less than 0.80 .

By looking at the overall estimation results based on existing criteria, overall good values are obtained. So from the analysis of the reliability of the LISREL 8.72 output for testing the overall model, it can be concluded that the model is good fit.

Structural Equation Analysis. This analysis is carried out on the coefficients of structural equations by specifying a certain level of significance. Analysis of this structural model is to test the hypotheses proposed in this study. For a significance level of 0.05 , the $t$ value of the structural equation must be greater or equal to 1.96 or to be practically greater than 2 (Wijanto, 2008).

From the whole hypothesis, it produces 1 equation which means there is 1 structural model proposed. From the equation in the structural model, it can be seen that all coefficients have significant $t$ values. This equation is the equation for the first and second hypotheses. It can be concluded that the hypotheses in this study are for $\mathrm{H} 1$ and $\mathrm{H} 2$, the results have proven to be significant. Intellectual capital management is proven to increase the success of MSMEs. The selection of the right competitive strategy has also been proven to have a significant positive impact on increasing the success or effectiveness of MSME management. Meanwhile, to assess how well the coefficient of determination of structural equations, will be seen from the magnitude of R2 (Wijanto, 2008). Lisrel test results that can be seen in the Reduced Form Equation obtained R2 values for each equation.

The first model has a value of $\mathrm{R}^{2} 0.90$ which means this model is able to explain $90 \%$ of changes in the variables of financial statement preparation motivation. The conclusion that can be drawn from this test is that the model is very good.

Overall $\mathrm{t}$ value of the two hypotheses proposed in this study the results can be summarized in the following table 6 .

Table 6. T-value for each hypothesis

\begin{tabular}{c|l|c|c|c}
\hline Hypothesis & \multicolumn{1}{|c|}{ Path } & Estimation & $\boldsymbol{t}$-value & Conclusion \\
\hline H1 & IC $\rightarrow$ MSMEs Performance & 0.81 & 7.26 & Significant \\
\hline H2 & $\begin{array}{l}\text { Competitive Strategy } \rightarrow \\
\text { MSMEs Performance }\end{array}$ & 0.21 & 2.09 & Significant \\
\hline
\end{tabular}

Analysis of Test Results. Each test result especially for testing the hypothesis proposed in this study is shown from the Lisrel output described in the previous section. From the two 
hypotheses put forward, all proved to be significant. The impact of managing intellectual capital has a positive effect on the success of MSMEs. Likewise, the variable selection of a competitive strategy has proven to affect the effectiveness of MSME management positively.

The resulting structural equation model confirms that the management of Intellectual Capital is proven to significantly affect the success rate of MSMEs. These results support the hypothesis proposed in this study. The better management of intellectual capital will further enhance the success of MSMEs. Intellectual capital can be used to improve MSME performance. This finding is in line with Resource-based View theory, that the unique resources that a company has will contribute to its ability to compete. The results of this study indicate that intellectual capital which is the company's unique resource will be able to improve the performance of MSMEs. The research confirms the results of previous similar studies that tested the positive relationship between intellectual capital and company performance, among others, conducted by (Istianingsih, 2012); (Baroroh, 2013); (Ciptaningsih, 2013); (Sirojudin and Nazaruddin, 2015) and (Tayles et al., 2007), (Tan et al., 2008). The higher intellectual capital owned by MSMEs will improve its performance.

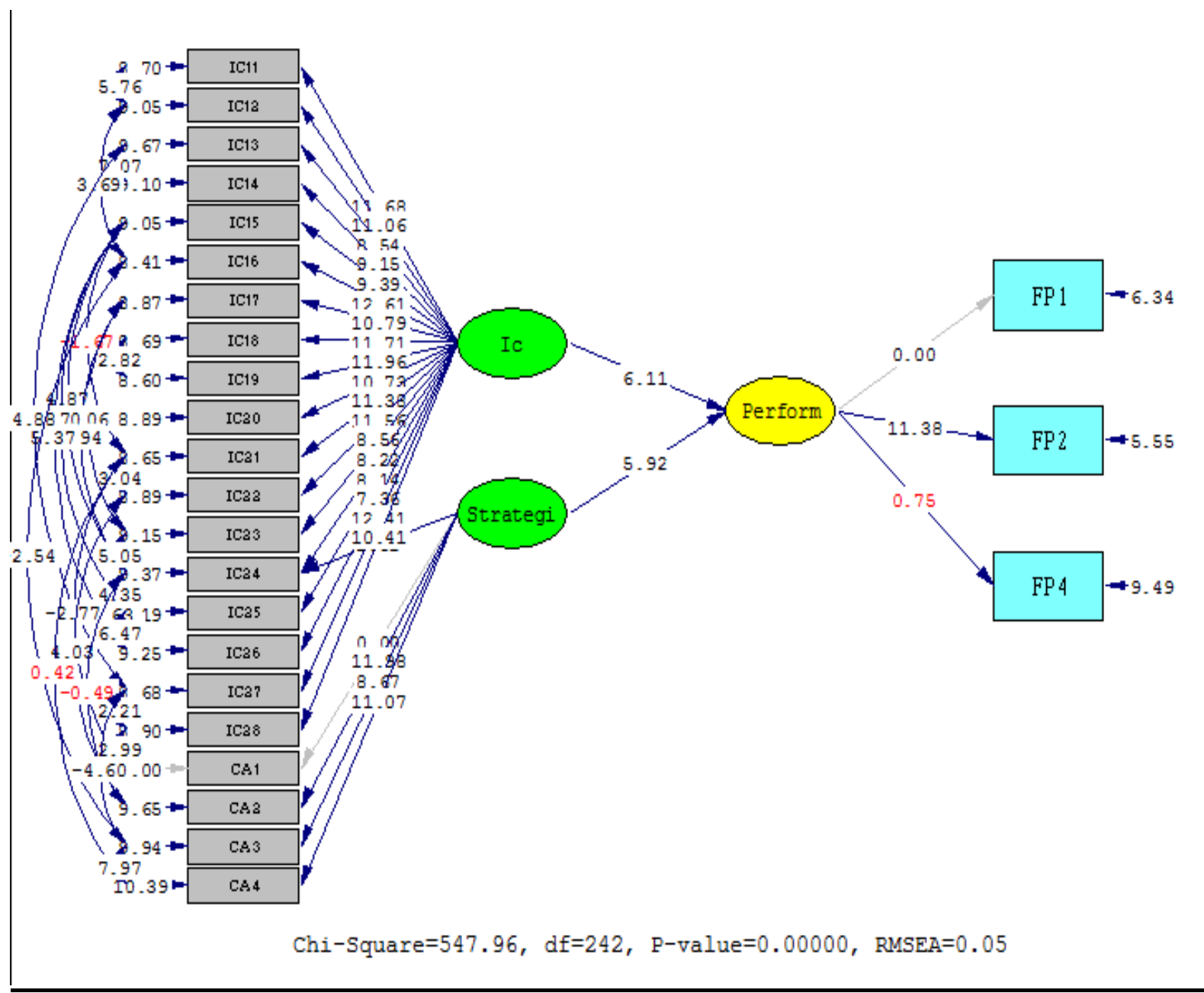


Figure 1. Structural Model T Test Results

The results of this study also confirm the results of research conducted by (Xu and Liu, 2020) who conducted research in the manufacturing sector. Their results indicate that intellectual capital is able to support companies in achieving competitive advantage. They stated that intellectual capital represented a valuable platform in the sustainable development of the manufacturing sector in the developing Asian market. This research is also in line with the results of (Allam, 2018). The findings of their study prove that there is a positive relationship between intellectual capital and accounting-based performance. However, their research found no evidence of a relationship between intellectual capital and market-based performance. The findings of (Allam, 2018) also reveal there are differences in the results of research between Saudi Arabia and Bahrain.

In this study there were three components of intellectual capital tested. The three components are human capital, relationship capital, and structural capital. Each component of intellectual capital should be managed properly in order to be beneficial for improving the performance of MSMEs. This research proves that the management of each component of intellectual capital properly will be able to encourage the effectiveness of MSME management in Banten.

In addition to the ability to manage intellectual capital, the selection of competitive strategies used by MSMEs will also determine the success rate of MSMEs in Banten. The results of this study support (Violinda, 2018). The right competitive strategy used to develop Micro, Small and Medium Enterprises (MSMEs) in Indonesia especially in Banten needs to be considered for the survival of MSMEs.

The rise of competition among similar SMEs with massive numbers is an important factor that needs to be considered in order to find suitable alternative strategies so that SMEs can win the competition. By choosing a competitive strategy that is able to describe how business units or companies compete in the same industry, MSMEs will undoubtedly survive the tide of competition. This competitive strategy enables MSMEs to gain competitive advantage over their competitors. The results of this study support the statements of previous researchers including (Istianingsih, 2012); (Adi 2016); and (Violinda, 2018), (Allam, 2018); and (Xu and Liu, 2020). The research results basically state that MSMEs that have competence in various functional fields, will be better able to remain competitive in the market. Companies that choose the right competitive strategy will be better able to compete and better able to deal with environmental uncertainty because it is supported by adequate skills.

\section{CONCLUSION}

This research is motivated by the importance of managing intellectual capital and choosing the right competitive strategy in order to improve MSME performance. By using a sample of MSME entrepreneurs in Banten, this study proposes two hypotheses. There are two factors tested for their impact on the performance of MSMEs in this study, namely intellectual capital and competitive strategy.

By using a sample of 181 respondents consisting of MSME owners in the Banten region, the following conclusions are generated: (1) Intellectual capital is proven to have a significant positive effect on the success rate of MSMEs. The greater the influence of 
Intellectual Capital that is felt by entrepreneurs, the more it will push the success rate of MSME management. (2) Competitive Strategy is proven to have a significant positive effect on the level of success in managing MSMEs. The choice of the right competitive strategy will encourage MSMEs to be better able to adapt to changing environments. The more appropriate choice of competitive strategy with the characteristics of MSMEs, the more it can improve the performance of MSMEs in Banten..

The results of this study support the various findings of previous researchers and add new understanding that in order to improve business performance and success, MSMEs need to manage Intellectual Capital properly and choose the right competitive strategy.

Implications of Research Results. This research has several implications for MSME entrepreneurs in Banten and possibly in other regions as well. MSME owners need to identify their intellectual capital ownership and manage it better. This research also has implications for other parties such as prospective MSME entrepreneurs and the government who want to encourage improvement in MSME performance. Counseling should be given to MSME entrepreneurs regarding the importance of managing intellectual capital. In addition, the government, through related agencies, needs to provide assistance to MSME owners in recognizing their business environment in order to be able to choose an appropriate competitive strategy. In addition, MSME entrepreneurs need to be encouraged to choose the right business strategy to win the competition.

Furthermore, the results of this study can be used as a reference for further research. Research related to intellectual capital and strategies for SMEs is still limited. Thus the results of this research give its own color given the still limited research literature on the application of competitive strategies in MSMEs and management of intellectual capital in order to win the competition.

Research Limitations. This study has several limitations that might affect the results of the research to be achieved. These limitations are: (1) The inherent limitations of the data obtained through the questionnaire, due to differences in the authors' perceptions with the research respondents. Although it has been tried to be minimized by conducting a preliminary test, but this limitation will still exist in studies that use primary data. (2) Limitations in the number of variables studied have an impact on the success of MSME management. Although the test results show that the ability of the two independent variables of this study to explain variations in changes in the success of MSME management is very high, it is also possible that there are still many other variables that have a great opportunity to influence the success of MSME. (3) Limitations on the selection of respondent samples that are not limited to MSME entrepreneurs with a certain amount of capital. Therefore, the results of this study cannot be used to differentiate the success rate of MSMEs between entrepreneurs with different amounts of resource ownership.

Development Suggestion. The suggestions for future research are as follows: (1) Future studies can develop this research using secondary data. By using secondary data, it is possible to obtain a picture of the amount of intellectual capital owned by each MSME. Future studies can also use other business strategy schemes such as those of (Porter, 1985ab) in order to obtain more complete analysis results. (2) Further research can also use other data sources such as interviews and field observations of MSMEs and banks to enrich the 
results of the analysis. (3) Future studies, it is recommended to use an expanded sample, in accordance with the rule of thumb on SEM and LISREL, so that testing can be carried out simultaneously using WLS estimation techniques. Adding this number of samples might be possible by extending the study period. (4) Further research can include other variables that can accommodate differences in the conditions of MSMEs in a wider area and with different levels of capital so that the results of the research are expected to be more in line with conditions in other regions in Indonesia.

\section{REFERENCES}

Allam Hamdan. (2018). Intellectual capital and firm performance: Differentiating between accounting-based and market-based performance", International Journal of Islamic and Middle Eastern Finance and Management, https://doi.org/10.1108/IMEFM-022017-0053.

Andi Munandar. (2016). The Strategy Development And Competitive Advantages Of Micro Small Medium Entreprise Business Institution Toward Regional Development. Adbispreneur: Jurnal Pemikiran Dan Penelitian Administrasi Bisnis Dan Kewirausahaan. Vol 4, No 3 (2019).

Barney, Jay. (1991). Firm Resources and Sustained Competitive Advantage. https://doi.org/10.1177/014920639101700108.

Baroroh, Niswah. (2013). Analisis Pengaruh Modal Intelektual Terhadap Kinerja Keuangan Perusahaan Manufaktur Di Indonesia. Jurnal Dinamika Akuntansi. Vol 5, No 2 (2013).

Bukh Per Nikolaj, Christian Nielsen, Peter Gormsen, Jan Mouritsen. (2005). Disclosure of information on intellectual capital in Danish IPO prospectuses. Accounting, Auditing \& Accountability Journal. https://doi.org/10.1108/09513570510627685.

Ciptaningsih, Tri. (2013). Uji Pengaruh Modal Intelektual Terhadap Kinerja Keuangan BUMN Yang Go Public Di Indonesia. Journal of Technology Management. Vol 12, No 3.

Deegan Craig. (2002). Introduction: The legitimising effect of social and environmental disclosures - a theoretical foundation. Accounting, Auditing \& Accountability Journal. https://doi.org/10.1108/09513570210435852.

Dinas Koperasi dan UKM Banten. (2020). Di akses dari https://dinkopukm.bantenprov.go.id tanggal 2 Februari 2020.

Eko Sulastri dan Rachma Zannati. (2018). Prediksi financial distress dalam mengukur kinerja perusahaan manufaktur. Jurnal Manajemen Strategi dan Aplikasi Bisnis. Vol 1 No 1 (2018). DOI: https://doi.org/10.36407/jmsab.v1i1.17.

Ghozali, Imam. (2011). Analisis multivariate lanjutandengan program SPSS. Semarang; Badan Penerbitan Universitas Diponegoro.

Hair, J., Anderson, R., Tatham, R. and Black, W. (2008). Multivariate Data Analysis. 7th edition. Englewood Cliffs, New Jersey, NJ: Prentice Hall.

Ikatan Akuntan Indonesia. (2009). Standar Akuntansi Keuangan Entitas Tanpa Akuntabilitas Publik. Jakarta: Salemba Empat

Istianingsih. (2012). Peran Strategi Bersaing dalam Memoderasi Hubungan Antara Intelektual Capital dan Kinerja Perusahaan. Jurnal Akuntansi. 16 (2), (176-190).

Kementrian Koperasi. (2019). UKM RI. Retrieved from http://www.depkop.go.id/. 
Kominfo. (2019). UMKM sudah GO Online. Economy. Retrieved from https://www.kominfo.go.id/content/detail/11526/kemenkop-ukm-379-juta-umkmsudah-go-online/0/sorotan_media.

Miles, R.W., Snow, C.C., (1978). Organizational Strategy, Structure and Process. McGraw Hill, New York.

Peteraf Margaret A. (1993). The cornerstones of competitive advantage: A resource-based view. https://doi.org/10.1002/smj.4250140303.

Porter, M.E., (1985a). Competitive advantage. Free Press, New York.

Porter, M.E., and Millar, V.E., (1985b). How information gives you competitive advantage. Harvard Business Rev. 63, 149-160.

Qrinstin Violinda. (2018). Strategi dan Keunggulan Bersaing Usaha Mikro Kecil, dan Menengah (UMKM) (Case Study pada UMKM di Semarang), Journal of Management and Business, Vol 1, No 1 (2018). DOI: https://doi.org/10.26877/sta.v1i1.2612.

Rudiantoro, Rizkidan dan Sylvia, Veronica Siregar. (2012). Kualitas laporan keuangan UMKM dan prospek implementasi SAK ETAP. JAKI, Jurnal Akuntansi dan $\begin{array}{lllllll}\text { Keuangan Indonesia. } & \text { Vol } & \text { 9, } & \text { No } & 1 & \text { (2012). }\end{array}$ http://dx.doi.org/10.21002/jaki.2012.01.

Sirojudin, Gatot Ahmad dan Nazaruddin, Ietje. (2015). Pengaruh Modal Intelektual dan Pengungkapannya Terhadap Nilai dan Kinerja Perusahaan. Journal of Accounting and Investment (JAI). Vol 15, No 2.

Sumbogo, Ignatius Ario dan Dara Siti Ruhana. (2020). Kajian Potensi Manusia Dan Bentang Alam Terhadap Rekonsiliasi Kehidupan Sosial Berbasis Manajemen Ekonomi Kawasan Das Citarum Kecamatan Rengasdengklok Kabupaten Karawang. Jurnal Riset Manajemen dan Bisnis (JRMB) Fakultas Ekonomi UNIAT. Vol 5 No 2 (2020).

Tan, HP, Plowman, D. and Hancock, P. (2008). The evolving research on intellectual capital. Journal of Intellectual Capital, Vol. 9 No. 4, 585-608.

Tayles, M., Pike, R., and Sofian, S. (2007). Intellectual Capital, Management Accounting Practices and Corporate Performance: Perceptions of Managers. Accounting, Auditing and Accountability Journal, 20 (4), 522.

Violinda Qristin. (2018). Dynamic Capabilities: Evidence from Agriculture Cooperatives in Indonesia. KnE Social Sciences.

Wijanto, S. (2008) Structural Equation Modeling dengan Lisrel 8.8. Graha Ilmu, Yogyakarta.

Xu, J., and Liu, F. (2020). The Impact of Intellectual Capital on Firm Performance: A Modified and Extended VAIC Model. Journal of Competitiveness, 12(1), 161-176. https://doi.org/10.7441/joc.2020.01.10.

Yuli Rachmini. (2017). Perkembangan Umkm (Usaha Mikro Kecil Dan Menengah) Di Indonesia. Jurnal Cano Ekonomos. Vol 6. No 1. 